\title{
Investigation of sorption mechanism of methylene blue, congo red and tannic acid from aqueous solutions onto magnetic composite sorbent obtained from alkaline pretreated spent coffee grounds
}

\author{
Pham Thanh Minh ${ }^{1 *}$, and Le Van Thuan ${ }^{2}$, \\ ${ }^{1}$ Center for Research and Production of Radioisotope, DaLat Nuclear Research Institute, DaLat, Vietnam \\ ${ }^{2}$ Center for Advanced Chemistry, Institute of Research \& Development, Duy Tan University, Danang, Vietnam
}

\begin{abstract}
In this article, a novel magnetic composite material obtained from alkaline pretreated spent coffee grounds was used for investigating of the sorption mechanism of methylene blue, congo red and tannic acid from aqueous solutions. In order to clarify mechanisms were analyzed the adsorption kinetics models (external and internal diffusion; chemical kinetics (pseudo-first order, pseudo-second order); intraparticle diffusion) and the adsorption thermodynamics. The results showed that the sorption of all studied sorbates was controlled by a mixed diffusion model and a pseudo-second order and diffusion rate revealed three stage of the mass transfer. The adsorption process of methylene blue, congo red and tannic acid onto $\mathrm{Fe}_{3} \mathrm{O}_{4} / \mathrm{PVA} / \mathrm{APSCG}$ sorbent was spontaneous and endothermic. Based on the results, it was concluded that the mechanism for removal of the studied sorbates by adsorption onto $\mathrm{Fe}_{3} \mathrm{O}_{4} / \mathrm{PVA} / \mathrm{APSCGs}$ sorbent may be assumed both physisorption and chemisorption.
\end{abstract}

\section{Introduction}

Many organic compounds like dyestuffs and aromatic compounds are commonly found in textile, paper, leather, plastics, food, cosmetics, and other industries. The toxic effects of these organic contaminants on human health, and the environment requires their efficient removal from contaminated water, and this topic becomes environmentally important [1].

Methylene blue (MB) is a cationic dye. It is found in almost textile for coloring. MB can cause toxicities for animals and humans, for example: if ingested, then $\mathrm{MB}$ causes convulsions, dyspnea, irritation to the skin, vomiting, and diarrhea [2].

Congo red (CR) is an anionic dye. It is found in the textile, paper, printing, leather industries, etc. It is a skin, eye, gastrointestinal, and respiratory irritant [3].

Tannic acid (TA) is a natural phenolic compound. It is found in most surface water, drinking water, and wastewater from plant medicine, paper and leather industries. TA has toxicity to aquatic organisms, such as algae, phytoplankton, fish, and invertebrates [4].

Recently, in order to solve technical problems related to the separation and regeneration of sorbents after adsorption process, various methods have been used like precipitation, coagulation, filtration or magnetic separation [5]. Particularly, magnetic separation technique is an effective method for separation of samples after adsorption using an external magnetic field [6]. To improve the potential application of magnetic separation techniques in the environment, new magnetic composite materials have to be developed based on the low-cost sorbents, in there, spent coffee grounds (SCGs) are a solid waste that is interested because the approach reduces the environmental and financial costs of disposal [7].

According to data publication, the magnetic composite sorbent obtained from spent coffee grounds (SCGs) has a high adsorption capacity towards organic dyes. Zuorro et al. [8] studied using magnetic coffee silverskin for methylene blue adsorption from aqueous solutions with a maximum adsorption capacity of 556 $\mathrm{mg} / \mathrm{g}$. Safarik et al. [9] studied magnetic coffee grounds for dyes removal (acridine orange, crystal violet, malachite green, Congo red, Bismarck brown Y, and safranin $\mathrm{O}$ ) and obtained the adsorption capacities from 9.34 to $73.4 \mathrm{mg} / \mathrm{g}$. Safarik et al. [10] studied magnetically responsive composite materials from coffee grounds for Bismarck brown Y and safranin O removal, the adsorption capacity reaching 49.3 and $146.6 \mathrm{mg} / \mathrm{g}$, respectively.

However, there is still no study devoted to the sorption mechanism of pollutants from aqueous solutions onto this magnetic composite sorbent. The purpose of this article was to study the sorption mechanism of organic dyes (methylene blue, congo red) and aromatic compounds (tannic acid) onto magnetic composite sorbents based on alkaline pretreated spent coffee grounds.

\section{Experimental}

Materials. SCGs were collected after brewing of Vietnamese commercial milled Robusta coffee and then 
the samples were washed with distilled water to remove dirt and color, and dried at $105{ }^{\circ} \mathrm{C}$ for 5 hours in a convection oven. The chemicals for the preparation of magnetite $\left(\mathrm{Fe}_{3} \mathrm{O}_{4}\right)$ particles: $\mathrm{FeCl}_{3} .6 \mathrm{H}_{2} \mathrm{O}, \mathrm{Na}_{2} \mathrm{SO}_{3}$, $\mathrm{NH}_{4} \mathrm{OH} 25 \%$, Polyvinyl alcohol (PVA) (M.W.: 146000186000, degree of hydrolysis: $99.5 \%$ ), and the sorbates such as Methylene blue (M.W.: $319.85 \mathrm{~g} / \mathrm{mol}$ ), Congo red (M.W.: $696.68 \mathrm{~g} / \mathrm{mol}$ ), Tannic acid (M.W.: 1701.21 $\mathrm{g} / \mathrm{mol})$.

Preparation of magnetic composite sorbent. The magnetic composite sorbent $\left(\mathrm{Fe}_{3} \mathrm{O}_{4} / \mathrm{PVA} / \mathrm{APSCGs}\right)$ based on alkaline pretreated spent coffee grounds (APSCGs) and particles $\mathrm{Fe}_{3} \mathrm{O}_{4}$ was prepared via dispersed method. To obtain this composite sorbent, the $\mathrm{Fe}_{3} \mathrm{O}_{4}$ particles were dispersed in PVA 2\% solution. Then, the sample was heated to $80^{\circ} \mathrm{C}$ and added in APSCGs at 4:1 ratio of APSCGs/ $/ \mathrm{Fe}_{3} \mathrm{O}_{4}$. Composite was collected by a magnet and sieved via a mesh size 315 $\mu \mathrm{m}$.

Adsorption kinetics. The adsorption kinetics of sorbates onto $\mathrm{Fe}_{3} \mathrm{O}_{4} / \mathrm{PVA} / \mathrm{APSCG}$ sorbent were studied in the change of the contact times to the adsorption capacity [11]. For each experiment, the samples $(0.1 \mathrm{~g})$ were mixed with $50 \mathrm{~mL}$ solutions sorbates of $\mathrm{MB}(0.15$ $\mathrm{mmol} / \mathrm{L}$ and $0.30 \mathrm{mmol} / \mathrm{L}), \mathrm{CR}(0.07 \mathrm{mmol} / \mathrm{L}$ and 0.14 $\mathrm{mmol} / \mathrm{L})$ and TA $(0.03 \mathrm{mmol} / \mathrm{L}$ and $0.06 \mathrm{mmol} / \mathrm{L})$. The experiments were performed at room temperature and pH 9 (MB), pH 5 (CR), pH 4 (TA). The concentration of sorbates in solutions was determined by spectrophotometric method using a SPECORD 210Plus spectrophotometer (Germany) at absorbance $666 \mathrm{~nm}$ (MB), $500 \mathrm{~nm}$ (CR), $275 \mathrm{~nm}$ (TA).

The amount of adsorbed sorbates onto the magnetic composite $q_{e}(\mathrm{mmol} / \mathrm{g})$ was calculated following to:

$$
q_{e}=\frac{C_{0}-C_{e}}{m} . V
$$

Where $C_{o}(\mathrm{mmol} / \mathrm{L})$ is the initial concentration of sorbates, $C_{e}(\mathrm{mmol} / \mathrm{L})$ is the equilibrium concentration of sorbates after adsorption, $V(\mathrm{~L})$ is the volume of solution and $m(\mathrm{~g})$ is the weight of sorbent.

Adsorption thermodynamics. To investigate adsorption thermodynamics, adsorption isotherms were constructed at different temperatures $298-318 \mathrm{~K}$ [12]. Batch experiments were performed at different initial concentrations of sorbates with values of $\mathrm{pH} 9(\mathrm{MB}), \mathrm{pH}$ 5 (CR), pH 4 (TA). After that, the samples were incubated in the water-batch thermostat for 8 hours. The concentration of sorbates in solutions was determined by spectrophotometric method.

\section{Results and discussion}

Investigation of the preparation and characterization of $\mathrm{Fe}_{3} \mathrm{O}_{4} / \mathrm{PVA} / \mathrm{APSCG}$ sorbent prepared from alkaline pretreated spent coffee grounds have been published in our articles [13, 14]. The results showed that the APSCGs have a significant amount of functional groups as carbonyl, carboxyl, hydroxyl on $\mathrm{Fe}_{3} \mathrm{O}_{4} / \mathrm{PVA} / \mathrm{APSCG}$ surfaces and these functional groups can be potential adsorption centers. SEM studies indicated that the morphology of composite has a porous structure with a size in the range of $2-50 \mu \mathrm{m}$, resulting in good adsorption capacity with different sizes. In addition, the saturation magnetization of the $\mathrm{Fe}_{3} \mathrm{O}_{4} / \mathrm{PVA} / \mathrm{APSCG}$ sorbent was $21.5 \mathrm{emu} / \mathrm{g}$, which is lower than the synthesized magnetite powder $73.6 \mathrm{emu} / \mathrm{g}$ but enough to separate sorbents after adsorption process. Using this technique, we were able to remove up to $95 \%$ of the sorbents from the solution $[13,14]$.

In this study, we used two important physicochemical aspects for the evaluation of adsorption mechanism as unit operations that are the adsorption kinetics and the adsorption thermodynamics. In addition, kinetic modeling using well - known models and adsorption thermodynamic parameters can be obtained from adsorption equilibrium constants at various temperatures. All studies were carried out trying to understand the involved mechanisms (physical and/or chemical) between sorbates molecules and on the sorbent surface.

Adsorption kinetics. To study the adsorption kinetics of sorbates on the surface of $\mathrm{Fe}_{3} \mathrm{O}_{4} / \mathrm{PVA} / \mathrm{APSCG}$ sorbent, the kinetic curves were analyzed using models of external and internal diffusion, intraparticle diffusion and chemical kinetics [13].

Analysis of kinetic curves was performed with the diffusion models[13]. Dependence has been constructed:

External diffusion: $-\ln (1-\mathrm{F})=\mathrm{f}(\mathrm{t})$

Internal diffusion: $F=f\left(t^{1 / 2}\right)$

where $F=q_{t} / q_{e}$ is the degree of completion of the adsorption process, in which $\mathrm{q}_{\mathrm{t}}$ and $\mathrm{q}_{\mathrm{e}}$ are the adsorption capacity of sorbates onto the composite at the time $t$ (hours (h)) and at equilibrium, respectively.

It is known that if the correlation coefficient $\left(\mathrm{R}^{2}\right)$ is closely related to dependencies, then the diffusional kinetics predominates over the limiting stage of those sorption process [14]. The results of the experimental data showed in Table 1. It can be seen that the correlation coefficient $\left(\mathrm{R}^{2}\right)$ for both models are quite satisfactory. This suggests that the adsorption process of $\mathrm{MB}, \mathrm{CR}$, and TA onto magnetic composite sorbent were controlled by a mixed-diffusion model.

To clarify the mechanisms that control the adsorption rate of multistage process we used the intraparticle diffusion model [15], which can be formulated as follows:

$$
q_{t}=k_{i d} t^{1 / 2}+C
$$

where $q_{t}(\mathrm{mmol} / \mathrm{g})$ is the adsorption capacity, $k_{i d}$ $\left(\mathrm{mmol} . \mathrm{g}^{-1} \cdot \mathrm{h}^{-1 / 2}\right)$ is the rate constant of intraparticle diffusion and $C(\mathrm{mmol} / \mathrm{g})$ is the intercept.

From Figure 1 can be seen that three continuous adsorption stages of $\mathrm{MB}, \mathrm{CR}$ and TA could occur.

The first stage characterized for the diffusion of $\mathrm{MB}$, $\mathrm{CR}$, and TA from the solution phase through the diffusion layer outside to the surface of the magnetic composite (external diffusion) [15]. The second stage refers to the diffusion of the $\mathrm{MB}, \mathrm{CR}$, and TA from surface of the magnetic composite to the adsorption centers (internal diffusion). The third stage was indicated to process of the formation bonds between the sorbates and the functional groups of the $\mathrm{Fe}_{3} \mathrm{O}_{4} / \mathrm{PVA} / \mathrm{APSCG}$ sorbent [16]. 
Table 1. Parameters Of Diffusion Models For Adsorption Of $\mathrm{mb}$, cr and ta Onto $\mathrm{Fe}_{3} \mathrm{O}_{4} / \mathrm{pva} /$ apscgs Sorbent

\begin{tabular}{|c|c|c|c|c|}
\hline \multirow{2}{*}{ Sorbate } & \multirow{2}{*}{$\begin{array}{c}\mathrm{C}_{\mathrm{o}} \\
(\mathrm{mmol} / \mathrm{l})\end{array}$} & \multicolumn{2}{|c|}{ Internal diffusion } & $\begin{array}{c}\text { External } \\
\text { diffusion }\end{array}$ \\
\cline { 3 - 5 } & & $\begin{array}{c}\mathrm{K}_{\text {id }} \\
(\mathrm{mmol} \mathrm{g} \\
\left.{ }^{1} \mathrm{~h}^{1 / 2}\right)\end{array}$ & $\mathrm{R}^{2}$ & $\mathrm{R}^{2}$ \\
\hline \multirow{2}{*}{$\mathrm{MB}$} & 0,15 & 0,419 & 0,983 & 0,990 \\
\cline { 2 - 5 } & 0,30 & 0,435 & 0,972 & 0,969 \\
\hline \multirow{2}{*}{$\mathrm{CR}$} & 0,07 & 0,305 & 0,978 & 0,981 \\
\cline { 2 - 5 } & 0,14 & 0,320 & 0,987 & 0,996 \\
\hline \multirow{2}{*}{$\mathrm{TA}$} & 0,03 & 0,262 & 0,992 & 0,993 \\
\cline { 2 - 5 } & 0,06 & 0,274 & 0,985 & 0,970 \\
\hline
\end{tabular}

To study the adsorption kinetics for $\mathrm{MB}, \mathrm{CR}$, and TA from aqueous solutions on the surface of magnetic composite sorbent we used the pseudo-first order model and pseudo-second order model and written as follow [17]:

The pseudo-first order model:

$$
\ln \left(\mathrm{q}_{e}-q_{t}\right)=\ln \mathrm{q}_{e}-k_{1} t
$$

The pseudo-second order model:

$$
\frac{t}{q_{t}}=\frac{1}{k_{2} q_{e}^{2}}+\frac{t}{q_{e}}
$$

where $\mathrm{q}_{\mathrm{e}}(\mathrm{mmol} / \mathrm{g})$ is the amount of adsorbed sorbates at equilibrium, $\mathrm{q}_{\mathrm{t}}(\mathrm{mmol} / \mathrm{g})$ is the amount of adsorbed sorbates at time $\mathrm{t}, \mathrm{k}_{1}\left(\mathrm{~h}^{-1}\right)$ and $\mathrm{k}_{2}\left(\mathrm{~g} \cdot \mathrm{mmol}^{-1} \mathrm{~h}^{-1}\right)$ are the rate constants for the first order model and second order model, respectively.

The results of the analysis parameters of the experimental data models are presented in Table 2. It is obvious that the pseudo-second order model described better the sorbates adsorption process onto magnetic composite sorbent because of its correlation coefficient $\left(\mathrm{R}^{2}\right)$ higher than the pseudo-first order model, and in all initial concentrations of sorbates, the calculated values $\mathrm{q}_{\mathrm{e}}$ of the pseudo-second order model have a better similar with the experimental values $\left(\mathrm{q}_{\mathrm{e}}\right.$, exp $)$.

From the data above it can be concluded that the adsorption process of sorbates $\mathrm{MB}, \mathrm{CR}$ and $\mathrm{TA}$ onto $\mathrm{Fe}_{3} \mathrm{O}_{4} / \mathrm{PVA} / \mathrm{APSCG}$ sorbent not only involves pore diffusion processes but also includes the formation of the interactions of sorbates with the functional groups of the sorbents.

Adsorption thermodynamics. Adsorption thermodynamic parameters were calculated using Langmuir constant $\left(\mathrm{K}_{\mathrm{L}}\right)$ from constructing the adsorption isotherms at different temperatures 298-318 K. The linear Langmuir adsorption isotherms are described by the following equations [18]:

$$
\frac{C_{e}}{q_{e}}=\frac{1}{q_{m} \cdot K_{L}}+\frac{C_{e}}{q_{m}}
$$

where $C_{e}(\mathrm{mmol} / \mathrm{L})$ is the equilibrium concentration of sorbates; $q_{e}(\mathrm{mmol} / \mathrm{g})$ is amount of adsorbed sorbates onto

the magnetic composite at equilibrium; $q_{m}(\mathrm{mmol} / \mathrm{g})$ is the maximum adsorption capacity, $K_{L}(\mathrm{~L} / \mathrm{mmol})$ is Langmuir constant.

Results (Table 4) showed that the adsorption isotherms of studied sorbates onto $\mathrm{Fe}_{3} \mathrm{O}_{4} / \mathrm{PVA} / \mathrm{APSCG}$ sorbent have a high adsorption capacity and increase with growth temperatures [19]. Comparison with many other common sorbents can be seen that $\mathrm{Fe}_{3} \mathrm{O}_{4} / \mathrm{PVA} / \mathrm{APSCG}$ sorbent have relatively high adsorption capacity among these adsorbents (Table 3 ). More importantly, the utilization of $\mathrm{Fe}_{3} \mathrm{O}_{4} / \mathrm{PVA} / \mathrm{APSCG}$ sorbent has a huge advantage of low cost due to the abundant resource of spent coffee grounds and sorbent after adsorption process can be easy for separating and regenerating from aqueous solution using an external magnet.

The thermodynamic parameters such as enthalpy change $\left(\Delta \mathrm{H}, \mathrm{kJ}^{\mathrm{m}} \mathrm{mol}^{-1}\right)$ and entropy change $\left(\Delta \mathrm{S}, \mathrm{J} . \mathrm{K}^{-}\right.$ $\left.{ }^{1} . \mathrm{mol}^{-1}\right)$ for the studied various temperatures were calculated using the Van't Hoff equation (8) and Gibbs free energy change $\left(\Delta \mathrm{G}, \mathrm{kJ} \cdot \mathrm{mol}^{-1}\right)$ by the equation (9) [20]:

$$
\begin{aligned}
& \ln K=\frac{\Delta S}{R}-\frac{\Delta H}{R T} \\
& \Delta G=-R T \ln K
\end{aligned}
$$

where $\mathrm{K}$ is the equilibrium constant, $\mathrm{K}$ was calculated as dimensionless by multiplying it by 55.5 (number of moles of water per liter of solution), then $K=K_{L} \times 55.5 \times 10^{3}(10), R$ is the universal gas constant $\left(8.314 \mathrm{~J} \cdot \mathrm{mol}^{-1} \mathrm{~K}^{-1}\right) ; T$ is the temperature $(\mathrm{K})$.

Thermodynamic parameters obtained are shown in Table 5. From the data presented in Table 5, it was evident that adsorption of all studied sorbates was endothermic since the value of $\Delta H$ is positive. Similar results for endothermic adsorption were also observed on adsorption on chitosan [21], bentonite [12], alkaline pretreated spent coffee grounds [22]. The positive value of $\Delta \mathrm{S}$ corresponding to the randomness rising at the solid-solution interface during the adsorption process [22]. In this study, the negative $\Delta G$ values indicated that adsorption sorbates onto the magnetic composite sorbent was spontaneous and adsorption capacity increased at higher temperatures.

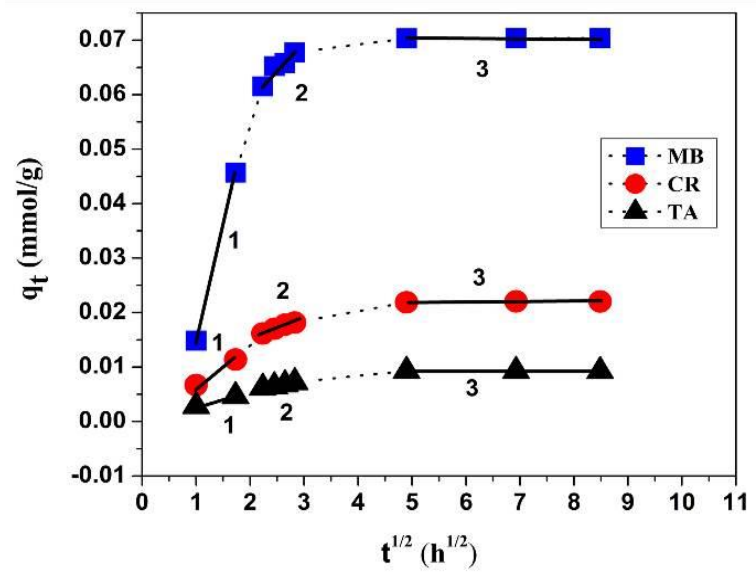

Fig. 1. Multistage process of $\mathrm{q}_{\mathrm{t}}$ at $\mathrm{t}^{1 / 2}$ for $\mathrm{MB}(0.15 \mathrm{mmol} / \mathrm{l})$, CR $(0.07 \mathrm{mmol} / \mathrm{l})$ and TA $(0.03 \mathrm{mmol} / \mathrm{l})$ adsorption at $298 \mathrm{~K}$ onto $\mathrm{Fe}_{3} \mathrm{O}_{4} / \mathrm{PVA} / \mathrm{APSCG}$ sorbent

Thus, according to the results of adsorption kinetic and thermodynamic studies, one might conclude that the mechanism for removal of the studied sorbates by adsorption onto magnetic composite sorbent $\mathrm{Fe}_{3} \mathrm{O}_{4} / \mathrm{PVA} / \mathrm{APSCG}$ may be assumed both physisorption (electrostatic interaction, internal and external pore diffusion and chemisorption (involve charge sharing or transfer from the organic molecules to the functional groups of sorbent surface to form a coordinate type of chemical bond. 
Table 2. Kinetic parameters for adsorption of mb, cr And ta Onto $\mathrm{Fe}_{3} \mathrm{O}_{4} / \mathrm{pva} / \mathrm{apscgs}$ Sorbent

\begin{tabular}{|c|c|c|c|c|c|c|c|c|}
\hline \multirow[b]{2}{*}{ Sorbate } & \multirow[b]{2}{*}{$\begin{array}{c}\mathrm{C}_{\mathrm{o}} \\
(\mathrm{mmol} / \mathrm{l})\end{array}$} & \multirow[b]{2}{*}{$\begin{array}{c}\text { qe exp } \\
(\mathrm{mmol} / \mathrm{g})\end{array}$} & \multicolumn{3}{|c|}{ Pseudo-first order model } & \multicolumn{3}{|c|}{ External diffusion } \\
\hline & & & $\begin{array}{c}\mathrm{k}_{1} \\
\left(\mathrm{~h}^{-1}\right)\end{array}$ & $\underset{(\mathrm{mmol} / \mathrm{g})}{\mathrm{q}_{\mathrm{e}}}$ & $\mathrm{R}^{2}$ & $\begin{array}{c}\mathrm{k}_{1} \\
\left(\mathrm{gmmol}^{-} \mathrm{h}^{-1}\right)\end{array}$ & $\begin{array}{c}\mathrm{Qe} \\
(\mathrm{mmol} / \mathrm{g})\end{array}$ & $\mathrm{R}^{2}$ \\
\hline \multirow{2}{*}{ MB } & 0,15 & 0,070 & 0,44 & 0,086 & 0,990 & 10,39 & 0,072 & 0,998 \\
\hline & 0,30 & 0,128 & 0,40 & 0,175 & 0,968 & 03,93 & 0,133 & 0,997 \\
\hline \multirow{2}{*}{$\mathrm{CR}$} & 0,07 & 0,022 & 0,22 & 0,018 & 0,980 & 20,46 & 0,023 & 0,999 \\
\hline & 0,14 & 0,041 & 0,29 & 0,037 & 0,996 & 16,07 & 0,042 & 0,999 \\
\hline \multirow{2}{*}{ TA } & 0,03 & 0,009 & 0,16 & 0,007 & 0,993 & 38,88 & 0,009 & 0,999 \\
\hline & 0,06 & 0,017 & 0,24 & 0,014 & 0,970 & 35,24 & 0,018 & 0,999 \\
\hline
\end{tabular}

Table 3. Comparison Of $\mathrm{q}_{\mathrm{m}}$ Value Of Different Sorbents For mb, cr, ta Adsorption

\begin{tabular}{|c|c|c|c|c|}
\hline Sorbent & Sorbate & Adsorption conditions & $\mathrm{q}_{\mathrm{m}},(\mathrm{mmol} / \mathrm{g})$ & References \\
\hline \multirow{3}{*}{$\mathrm{Fe}_{3} \mathrm{O}_{4} / \mathrm{PVA} / \mathrm{APSCGs}$} & MB & $\mathrm{pH} 9,25^{\circ} \mathrm{C}, 24 \mathrm{~h}$ & 0,369 & \multirow{3}{*}{ In present study } \\
\hline & $\mathrm{CR}$ & $\mathrm{pH} 4,25^{\circ} \mathrm{C}, 24 \mathrm{~h}$ & 0,088 & \\
\hline & TA & $\mathrm{pH} 5,25^{\circ} \mathrm{C}, 24 \mathrm{~h}$ & 0,066 & \\
\hline Spent coffee grounds & MB & $\mathrm{pH} 5,25^{\circ} \mathrm{C}, 12 \mathrm{~h}$ & 0,059 & [21] \\
\hline Magnetically modified coffee silverskin & MB & $\mathrm{pH} 6,20^{\circ} \mathrm{C}, 6 \mathrm{~h}$ & 1,738 & [8] \\
\hline $\begin{array}{l}\text { Magnetically modified spent coffee } \\
\text { grounds }\end{array}$ & $\mathrm{CR}$ & $\mathrm{pH} 4,25^{\circ} \mathrm{C}, 3 \mathrm{~h}$ & 0,014 & [9] \\
\hline Zeolite SMZ-CBC & TA & $\mathrm{pH} 5,525^{\circ} \mathrm{C}, 24 \mathrm{~h}$ & 0,065 & [22] \\
\hline Nano sorbent $\mathrm{Fe}_{3} \mathrm{O}_{4} @ \mathrm{SiO}_{2}-\mathrm{NH}_{2}$ & TA & $\mathrm{pH} 6,25^{\circ} \mathrm{C}, 24 \mathrm{~h}$ & 0,08 & {$[4]$} \\
\hline
\end{tabular}

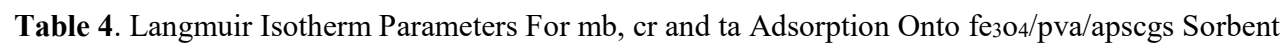

\begin{tabular}{|c|c|c|c|c|}
\hline \multirow{2}{*}{ Sorbate } & \multirow{2}{*}{$\mathrm{T}(\mathrm{K})$} & \multicolumn{3}{|c|}{ Langmuir model } \\
\cline { 3 - 5 } & & $\mathrm{K}_{1}(\mathrm{~L} / \mathrm{mmol})$ & $\mathrm{q}_{\max }(\mathrm{mmol} / \mathrm{g})$ & $\mathrm{R}^{2}$ \\
\hline \multirow{3}{*}{$\mathrm{NB}$} & 298 & 11,31 & 0,396 & 0,987 \\
\cline { 2 - 5 } & 308 & 20,29 & 0,613 & 0,995 \\
\cline { 2 - 5 } & 318 & 23,96 & 0,711 & 0,996 \\
\cline { 2 - 5 } & 298 & 13,97 & 0,088 & 0,985 \\
\cline { 2 - 5 } & 308 & 15,53 & 0,108 & 0,997 \\
\cline { 2 - 5 } & 318 & 25,55 & 0,066 & 0,987 \\
\cline { 2 - 5 } & 298 & 16,08 & 0,082 & 0,993 \\
\cline { 2 - 5 } & 308 & 19,32 & 0,084 & 0,994 \\
\hline
\end{tabular}

Table 5. Thermodynamic Parameters Adsorption mb, cr and ta Onto $\mathrm{Fe}_{30} \mathrm{O} / \mathrm{pva} / \mathrm{apscgs}$ Sorbent

\begin{tabular}{|c|c|c|c|c|}
\hline Sorbate & $\mathrm{T}(\mathrm{K})$ & $\Delta \mathrm{G}$ & $\Delta \mathrm{H}$ & $\Delta \mathrm{S}$ \\
\hline \multirow{3}{*}{ MB } & 298 & $-33,07$ & \multirow{3}{*}{29,76} & \multirow{3}{*}{221.37} \\
\hline & 308 & $-35,68$ & & \\
\hline & 318 & $-37,28$ & & \\
\hline \multirow{3}{*}{$\mathrm{CR}$} & 298 & $-33,60$ & \multirow{3}{*}{18,75} & \multirow{3}{*}{175,28} \\
\hline & 308 & $-35,00$ & & \\
\hline & 318 & $-37,12$ & & \\
\hline TA & 298 & $-33,95$ & 15,09 & 164,51 \\
\hline
\end{tabular}

\section{Conclusion}

The composite sorbent obtained from alkaline pretreated spent coffee grounds and the synthetic magnetite has a high sorption capacity towards sorbates MB, CR, and TA. Adsorption of sorbates was controlled by a mixed diffusion model and pseudo-second order model.
Detailed analysis of $\mathrm{q}_{\mathrm{e}}$ dependence on $t^{1 / 2}$ allowed to distinguish three separate stages of the process.

The results of determination of thermodynamic parameters $\Delta \mathrm{G}, \Delta \mathrm{H}$ and $\Delta \mathrm{S}$ showed that the process of adsorption of sorbates was shown to be an endothermic one and adsorption mechanism may be a combination of both physisorption and chemisorption. 


\section{Acknowledgment}

This work was supported by Graduate University of Science and Technology under grant number GUST.STS.ĐT2017-KHVL02.

\section{References}

1. M. T. Amin, a a Alazba, and U. Manzoor, "A review on removal of pollutants from water / wastewater using different types of nanomaterials," 2014 (2014)

2. X. He, K. B. Male, P. N. Nesterenko, D. Brabazon, B. Paull, and J. H. T. Luong, ACS Appl. Mater. Interfaces, 5(17), 8796-8804 (2013)

3. .S. Munagapati and D. S. Kim, J. Mol. Liq., 220, 540-548 (2016)

4. J. Wang, C. Zheng, S. Ding, H. Ma, and Y. Ji, Desalination, 273, 285-291 (2011)

5. D. Mohan, H. Kumar, A. Sarswat, M. AlexandreFranco, and C. U. Pittman, Chem. Eng. J., 236, 513-528 (2014)

6. I. Šafařík, K. Nymburská, and M. Šafaříková, J. Chem. Technol. Biotechnol., 69, 1, 1-4 (1997)

7. M. H. Baek, C. O. Ijagbemi, S. J. O, and D. S. Kim, J. Hazard. Mater., 176, , 820-828 (2010)

8. A. Zuorro, A. Di Battista, and R. Lavecchia, Chem. Eng. Trans., 35, 1375-1380 (2013).

9. I. Safarik, K. Horska, B. Svobodova, and M. Safarikova, Eur. Food Res. Technol., 234(2), 345350 (2012)

10. I. Safarik, K. Horska, K. Pospiskova, Z. Maderova, and M. Safarikova, IEEE Trans. Magn., 49(1), 213218 (2013)

11. Kannan and M. M. Sundaram, "Kinetics and mechanism of removal of methylene blue by adsorption on various carbons - a comparative study," Dye. Pigment., 51(1), pp. 25-40 (2001)

12. S. Hong, C. Wen, J. He, F. Gan, and Y. S. Ho, J. Hazard. Mater., 167, , 630-633 (2009)

13. C. Sarici-Ozdemir, Physicochem. Probl. Miner. Process., 48(2), 441-454 (2012)
14. O. V. Perlova, V. F. Sazonova, N. A. Perlova, and N. A. Yaroshenko, Russ. J. Phys. Chem. A, 88(6), 1012-1016 (2014)

15. E. Lorenc-Grabowska, G. Gryglewicz, and M. A. Diez, "Kinetics and equilibrium study of phenol adsorption on nitrogen-enriched activated carbons," Fuel, 114, pp. 235-243 (2013)

16. T. Feng and L. Xu, Adv. Mater. Res., 690-693, 438-441 (2013)

17. Y. Lei, J.-J. Guan, W. Chen, Q.-F. Ke, C.-Q. Zhang, and Y.-P. Guo, RSC Adv., 5(32), 25462-25470 (2015)

18. P. Hou, C. Shi, L. Wu, and X. Hou, Microchem. J., 128, 218-225 (2016)

19. J. He, S. Hong, L. Zhang, F. Gan, and Y. S. Ho, Fresenius Environ. Bull., 19(11A), 2651-2656 (2010)

20. A. Ramesh, D. J. Lee, and J. W. C. Wong, J. Colloid Interface Sci., 291(2) 588-592, (2005)

21. S. Banerjee and M. C. Chattopadhyaya, Arab. J. Chem., 10, S1629-S1638 (2017)

22. Y. Dai, D. Zhang, and K. Zhang, J. Taiwan Inst. Chem. Eng., 68, 232-238 (2016)

23. P. Llewellyn, Adsorption by Ordered Mesoporous Materials, 2nd ed. Elsevier Ltd. (2013)

24. C. C. Rodrigues, D. Moraes, and U. F. De, Technology, 2(1), 1013-1022 (2002)

25. A. Zarrouk, B. Hammouti, H. Zarrok, and M. Messali, "Temperature Effect, Activation Energies and Thermodynamic Adsorption Studies of LCysteine Methyl Ester Hydrochloride As Copper Corrosion Inhibitor In Nitric Acid 2M," 6, pp. 6261-6274 (2011)

26. H. Chen, J. Zhao, and G. Dai, J. Hazard. Mater., 186, 1320-1327 (2011)

27. D. C. Emeniru, O. D. Onukwuli, P. Douyewodu, and B. I. Okoro, "The Equilibrium and Thermodynamics of Methylene Blue Uptake onto Ekowe Clay ; Influence of Acid Activation and Calcination," 5, $17-25$ (2015) 